\title{
Socialist elements in Soviet design ideology
}

In this presentation, I will aim to define the Socialist elements of Soviet design ideology during late socialism. I will discuss the Soviet Union in general and define only the ideological qualities of the Soviet design and how they related to questions of form. As Soviet-made products often follow the same design stylistics as Western objects of the same period, it may seem difficult to find a certain design ideology behind them or to pinpoint the Socialist qualities of design. I will argue that the main characteristics of Soviet design ideology are not located in the form of the objects, but rather in their mode of production. Despite the different control mechanisms, there was no centralized organ responsible for industrial design and products were judged mostly on economic or technological grounds. While there were many books and articles on Soviet design and design ideology, none of them actually discuss the questions of form, but rather deal with economics and the purpose of design. Therefore, designers had some artistic freedom and were able to follow modern trends. The ideological qualities of design were hidden rather in the physical and ideological context of production, adding a Socialist quality to all Soviet-made objects.

keywords Soviet Union, socialism, ideology, industrial design, mass production

The aim of this presentation is to analyse the elements of Socialist principles in Soviet design ideology during late socialism. If we look at items mass-produced in the Soviet Union during late Socialism, it can almost be surprising how similar some of them are to the Western-made objects. Their material may be cheaper and quality slightly worse, due to the technological backwardness of Soviet factories, but stylistically they follow the same traditions, occasionally even copying specific Western objects. Therefore, the nature of Soviet design ideology and their accordance with Socialist ideals may seem unclear at a first glance.

I will be discussing the Soviet Union in general and defining only the ideological qualities of the Soviet design as a concept. The actual functioning is a lot more complicated, as it is virtually impossible to describe a "typical Soviet citizen" or a "typical Soviet factory" - the Soviet Union extended from the Baltic countries to the Far East and, during late socialism, had a quarter billion inhabitants. During late Socialist era, the initial enthusiasm of Lenin's ideals or the seeming liberation of the Thaw had faded. However, as the post-war era saw great financial difficulties throughout the Soviet Union, the birth of industrial design as a discipline did not happen until 1962 with the founding of VNIITE, the USSR Research Institute of Industrial Design. Therefore, it is only in the 1960 s when we can start talking about a defined design ideology. The design of actual objects was, besides the Soviet ideology, also shaped by other factors such as Western influences, national identity and 
theme 5

society

Figure 1.

Glass set for factory Tarbeklaas in Estonia (1961). Designer Ingi Vaher. Photo: courtesy of Estonian Museum of Applied Arts and Design. strand 1

design policies

individual tastes. I will mostly be comparing the Soviet design and design ideology against its Western counterparts, as the Western capitalist world was the main background system and point of comparison for the more informed Soviet citizens. Naturally, the Western trends were more apparent in the Western parts of the Soviet Union; however, they also trickled down to the Eastern areas.

The main aspect that should be stressed was the rigorous control to which industrial design was subjected. Each new product had to be mandated from above by a formal document called a prikaz (order), which announced a decision. (Lawrence and Vlachoutsicos 1990: 258) No object could go into production without passing an evaluation by the Art Council, comprised of specialists. Different standards were created - initially to ensure that the quality of design throughout the Soviet Union would be on an equally high level, but in reality they became instruments of control. (Azrikan 1999: 53) However, design was not properly centralized. There was no bureaucratic institution directly responsible for design, its different aspects were scattered around. Therefore, bureaucracy related to industrial design was even more complicated than usually in the Soviet context, belonging to several spheres at once. Yet, the ideological factor was the existence of the system of control, not the control itself. Most decisions were based on economic and aesthetic considerations, not ideological.

In a way, the reason why we can talk about an ideological quality in Soviet design is not just the existence of texts considering it, but also the fact that the Soviet government tried to cover every aspect of life with ideology. It was unthinkable that any detail in everyday life would be ideologically neutral, as by Marxist-Leninist standards everything was ideologically charged. As said by Herbert Dubin, a Latvian design ideologue: "The object as a materialized representative of certain social relations does not exist outside of our contemporary ideological life. Therefore designer is also an active warrior in ideological front." (Dubin 1977: 5) Designers were supposed to be the carriers of Soviet ideology: much like everyone else in the cultural field, they had to contribute to the making of a new Socialist environment. Design was not just the object of control, but also actively used as an instrument for exercising control. For example, furniture was often designed in a way that its arrangement, especially in new flats, was almost completely predetermined. (Gerchuk 2000: 92) This way, the state had another tool for controlling and shaping the Soviet citizens.

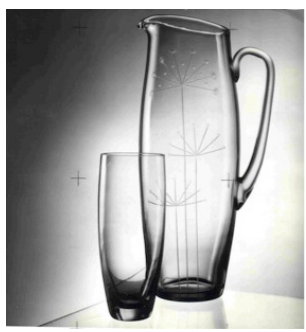

It is important to stress that in the Soviet context, design had a very different position. To quote Dmitry Azrikan: "Design, having an obvious Western face, nature, and genesis, could be accepted as only a tool and not as an autonomous phenomenon with its own place and role in Soviet culture." (Azrikan 1999: 48) Therefore, design was just a tool used for the ultimate goal, never the objective itself. Here, design in its broadest sense could be compared to technology and the debates surrounding it at the beginning of the 
2oth century. In Lenin's own words: "The Soviet Republic must at all costs adopt all that is valuable in the achievements of science and technology in this field. The possibility of building socialism depends exactly upon our success in combining the Soviet power and the Soviet organization of administration with the up-to-date achievements of capitalism." (Lenin 1918) This quote actually explains the readiness to adopt Western design influences. Socialism was never intended to negate its capitalist past, but rather to take everything valuable from that experience and build a new system on that foundation. After all, the problem socialism had with capitalism was not based on technological grounds, but social. Adopting Western design stylistics is merely an example of the same tendencies.

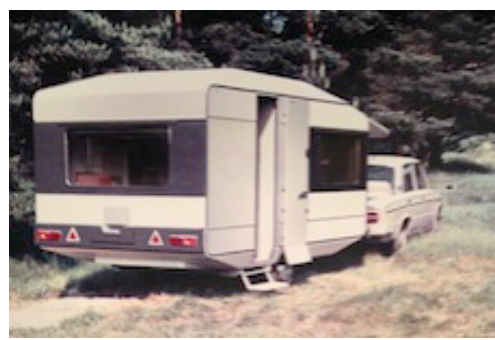

The idea and appearance of modernism went very well with the Soviet ideology: modern objects were simple, functional and easy to produce in factory conditions. Some of the Soviet ideologues even claimed that, in fact, modernism clashed with the capitalist ideology; for example, Karl Kantor argued that modernism was caused by a protest against private property and "bourgeois individualism".(Kantor 1976: 5) Often, references were made to the Bauhaus school and its opposition to the Nazi power; Hannes Meyer and his escape to the Soviet Union were an especially loved subject. Naturally, none of these authors mention Meyer's escape from the Soviet Union some years later. However, these theories often seemed to be excuses. As the designers were already influenced by Western trends and aiming to keep up with the rest of the world, it was necessary to justify this behaviour.

Design ideologies offered very few guidelines about the ideal Soviet form or how exactly was it supposed to contribute to the aesthetic education. Here, I would like to refer to the book "Artistic construction of industrial objects", written by the Russian design philosopher Yuri Somov in 1967. It was one of the first books written on the problems of industrial design. Somov mostly discusses the importance of economic considerations. He preaches rationalism, even claiming that throughout the history, the objects of best artistic quality are created with the minimum use of decorative means. (Somov 1971: 138) Somov does not advocate Western design, instead he accuses functionalism of lacking a "human factor" without explaining its differences from the economic-rational approach he teaches. Therefore, it is only logical that the "human factor" is added solely by the Socialist environment of production and it is the surrounding ideology that somehow validates the design ideology. Raymond Hutchings, one of the first Western authors to discuss Soviet design ideology, also admits that design forms are just a minor part of design ideology as a whole: "Ideology is rarely exerted without admixture of other elements. More often it is exerted through particular sets of economic priorities or organizational structures which have, among other foundations, an ideological one." (Hutchings 1978: 72)
Figure 2.

Caravan 375 for the Tupolev Machinery Factory in Russia (1982). Designer Matti Öunapuu. Photo: courtesy of Estonian Museum of Applied Arts and Design. 
"Although on the outside the achievements of design may be similar here and in a capitalist society, it is not this similarity that defines their status in society. Status, place and part are defined by whether design depends on private capital like in a capitalist society or it belongs to the sphere of material and intellectual culture like in socialism. This principal difference gives our design as a cultural factor the opportunity to lose the fetishism and chaos of objects and to stimulate the creation of a harmonic material environment."(Tinn 1976: 8)

It was officially maintained that in the West, people liked the right things, but for the wrong reasons. This treatment is due to the complex nature of ideology as such. It consisted not only of the object, but also of its production, reception and textual justification. If some of the elements vary, the outcome of the ideology itself is different.

Citing Nicos Poulantzas: "Ideology does not consist merely in a system of ideas or representations: it also involves a series of material practices, embracing the customs and life-style of the agents and setting like cement in the totality of social (including political and economic) practices."(Poulantzas 1978: 28) Therefore, in order to fully understand design ideology, it is necessary to also look at ways design is produced and received. In Soviet context these material practices differ greatly from those in the West, thus further adding to the different layers of ideology. Design was already ideologically correct because of the way it was produced. Art and craft are less subjected a direct state control and therefore include a certain moment of rebellion against the system. Massproduced design, however, already involves numerous people in its production; it is also produced in a factory that, in USSR, belongs to the state itself. Maxim Gorky called the factory an "organizer of the socialist consciousness." (Oushakine 2004: 405) The factory as an ideologically correct location, with the participation of a large number of people (especially as many of them were probably members of the Communist Party) validates the object itself. The fact that something has been produced in a factory already shows accordance with the system.

Therefore, we can say that the defining Socialist factors of the Soviet design ideology are actually:

1. The general ideologically charged context

2. Dependency on the state

3. The integration of artists within the Socialist factory environment and their participation in the factory as "an organizer of the socialist consciousness" 4. Location within the system of control

However, the nature of Soviet design ideology remained unclear, as these factors are not enough to form a clear doctrine. This problem was caused by several different factors: the complex status of design within the Soviet society, the lack of a consensus between different ideologues and, most importantly, a lack of a definite visually distinguishable aesthetic style. For designers, it was naturally beneficial, as it meant less control and more artistic freedom. Most restrictions were technological and economical, leaving design aesthetics to evolve on their own. The context and environment ideologized the industrial design, regardless of its form.

\section{Conclusion}

Soviet factory design often followed the same trends as Western design, although it was a few years behind and tended to be technologically inferior. It is important to stress that 
in the Soviet context, the Socialist ideas are hidden rather in the context and practices surrounding design than in the actual forms of design. Design was intended to be a tool for conveying a message. In spite of the various control mechanisms, the Soviet system lacked a specific centralized organ in charge of industrial design and products were judged mostly on economic or technological grounds. Therefore, designers had some artistic freedom and were able to follow modern traditions. There were two reasons for accepting modernism in Soviet ideology: firstly, because modern objects were easy to produce in factory conditions, and secondly, because there was never a clear definition of Soviet form. The main Socialist factor that makes design produced in the Soviet Union acceptable within Socialist ideology is the surrounding ideology. Industrial design depended on the state and was located within the general system of control, being both the agent and the subject of control. Last but not least, the direct production environment of industrial design was factory as the most ideologically charged context in the Socialist environment. However, if context ideologizes the content - is there a capitalist design and design ideology? And how would one characterize them?

\section{References}

Azrikan, D. (1999) 'VNIITE, Dinosaur of Totalitarianism or Plato's Academy of Design?' Design Issues, vol 15, pp 45-77.

Dubin, H. (1977) Disain sotsialistliku nüüdiskultuuri süsteemis [Design in the system of contemporary socialist culture. Sirp ja Vasar, 15/04/1977.

Gerchuk, I. (2000) The Aesthetics of Everyday Life in the Khrushchev Thaw in the USSR (1954-64). In: Crowley, D. \& Reid, S. E. (eds.) Style and socialism: modernity and material culture in post-war Eastern Europe. Oxford: Berg.

Hutchings, R. (1978) 'Soviet Design: The Neglected Partner of Soviet Science and Technology'. Slavic Review, vol 37, pp 567-583.

Kantor, K. (1976) Ilu ja tulu [Beauty and benefit]. Sirp ja Vasar, 16/07/1976.

Lawrence, P. R., \& Vlachoutsicos, C. (1990). Behind the factory walls : decision making in Soviet and US enterprises. Boston, Mass.: Harvard Business School Press.

Lenin, V. (1918) The Immediate Tasks of the Soviet Government [Online]. : Available: http://marxists.org/archive/lenin/works/1918/mar/xo3.htm.

Oushakine, S. A. (2004) 'The Flexible and the Pliant: Disturbed Organisms of Soviet Modernity'. Cultural Anthropology, vol 19, pp 392-428.

Poulantzas, N. (1978) State, power, socialism, London, New Left Books.

Roth, P. (1987) Propaganda as an instrument of power. In: VEEN, H.-J. (ed.) From Brezhnev to Gorbachev. Domestic affairs and Soviet foreign policy. Leamington Spa: Berg.

Somov, Y. (1971) Tööstustoodete kunstiline konstrueerimine [Artistic construction of industrial objects]. Tallinn: Valgus.

Tinn, E. (1976) Disain [Design]. Sirp ja Vasar, 14/05/1976. 
